\title{
The Connection Between Counseling Psychology and Christian Spiritual Direction
}

\author{
Frans Laka Lazar \\ \{franslaka67@gmail.com\} \\ Universitas Katolik Indonesia St. Paulus Ruteng
}

\begin{abstract}
Counseling psychology and Christian spiritual direction are the helping relationships to assist a counselee or the guided to overcome his personal problems and relationship with God. The research objective is to describe the relationship between counseling psychology and Christian spiritual direction. To achieve this goal, the researcher uses the literature method with the steps of recording various findings related to this topic, integrating various theoretical findings, and then analyzing and formulating them in a complete paper. The results showed that these two forms of approaches have a strong correlation as a means of helping. Therefore, the researcher suggests that both forms of guidance could be used at the same time because they consider humans as social as well as spiritual beings.
\end{abstract}

Keywords: Counseling, Psychology, Guidance, Spiritual Direction

\section{Introduction}

Guidance and counseling and Christian spiritual direction are in the realm of the helping relationships, it means that both approaches play a role in helping someone to overcome his/her personal problems. Guidance and counseling is the psychological help given by a person (counselor, a more skilled and experienced person) with another person (counselee, client, or mentor) who is experiencing personal and social problems that need help to overcome it. Guidance and counseling aim is to help a person understand himself in various life dimensions such as personality, social, education, career, moral, religion, and so on; help individuals to make wiser choices, decisions, and life plans; help someone develop his potential to the maximum, and help self-management more effectively and efficiently [1].

Christian spiritual direction is an assistance provided by a spiritual counselor or spiritual director (pastor, monk, and laypeople who have sufficient knowledge of theology and spirituality) to a guided person to overcome his human problems of faith in order to grow and develop become a more mature person in terms of faith, hope, and love. The presence of spiritual counselor is a facilitator who is in charge of helping the guided person to build deeper personal relationship with God. In general, the role of the spiritual counselor is to assist a guided person to interpret every human experience in the light of the experience of God.

In overcoming counselee's problem or a guided person who believes in God Almighty, the two approaches can be given integrally where the dimensions of psychology and spiritual problems can be discussed together and resolved at once. This is in line with the new movement that sees humans as spiritual beings (SQ) [2] where the counselee is helped to see and understand his life meaning as a unique person and created by God. 


\section{Methodology}

The method used in this study is library research. The researcher read various literature taken from books and journal articles related to the topic of counseling psychology and christian spiritual direction. The sources of the literature were read and analyzed carefully, integrated, interpreted and formulated creatively to produce this article [3]. The objective of this study is to describe the connection between counseling psychology and christian spiritual direction to assist a person.

\section{Result and Discussion}

\subsection{Food Guidance and counseling}

The terms guidance and counseling are often used interchangeably, but theoretically, the two are different. Guidance has a broader meaning than counseling and counseling is a part of guidance. Guidance is the assistance given by a person to another with the aim of helping that person is to make the right choice, and understand himself and his environment and develop his potential to be more mature [4]. The characteristics of guidance are as follows. First, guidance is preventive in nature, it means that it provides prevention before the problem occurs and is experienced by a guided person. Second, guidance can be carried out by anyone including parents, teachers, or older people. Third, guidance is carried out without having a systematic structure, or guidance is given informally in the form of providing information, advice, and so on. Fourth, guidance can be given individually or in groups.

Counseling can be defined as a relationship between counselor and counselee where the counselor is a professional who help the counselee to overcome his personal and social problems [5]. In addition to this definition, there is also a more complete definition given by Sofyan S. Willis [6], that counseling is an effort of helping relationship provided by an educated, trained, and experienced counselor to a counselee who need help, and is able to adjust to an everchanging environment.

Based on the above definitions, there are some general characteristics of counseling can be formulated. First, counseling is an interaction between two people where there is direct communication between counselor and counselee. Second, the media used in counseling interactions is verbal language. Third, the counseling interaction occurs within a period of time that is agreed upon by counselor and counselee, ranging from 45-60 minutes. Fourth, the purpose of counseling interaction is to help a counselee overcome his problems. Fifth, counseling is carried out in a structured and systematic manner, and with certain skills that must be mastered by counselor so that the counseling process can run smoothly and achieve the objectives of counseling, namely changes in a counselee.

\subsection{The Role of Guidance and Counseling}

Guidance and counseling have an important role in solving the counselee's problems. The role of guidance and counseling are as follows [7]. First, help a person to understand his/her self with all aspects of his personality and also the environment in which he lives with all his relationships and dynamics. Self-understanding includes all potentials, abilities, traits, characteristics, and understands the environment that adheres to its formation such as family, school, and society. 
Second, help a person to prevent the problems not to happen in the future. In counseling, counselor provides certain tips to a counselee to prevent various problems that will occur. Third, help a person to a curative or healing action. It means that counseling is given with the aim of overcoming various problems that occur and are experienced by a counselee. Counselors with his/her professionalism and experiences try to help a counselee to overcome his problems. Fourth, maintain and develop positive potential in individuals. Counseling helps individuals to maintain and care for good and positive things, and if necessary, the good and positive elements are developed to be even better until they become mature humanly and spiritually.

\subsection{Spiritual Direction}

The term spiritual direction is often used in Christian accompaniment. In English, spiritual guidance is called spiritual direction, and spiritual guide called spiritual director. According to William A. Barry, and William J. Connolly, [8], "spiritual direction is the help given by one Christian to another, which enables that person to pay attention to God's personnel communication to him/her, to grow in intimacy with his God, and to live out the consequences of the relationship". This definition emphasizes that in spiritual direction a Christian tries to help others to build a more intense relationship and communication with God for his spiritual growth. Wright further defines "spiritual direction is an interpersonal situation in which one person assists another to develop and to be more mature". Wright maintains that spiritual direction is a situation where someone helps others to grow towards life maturity of faith, love, and hope. Living in faith is related to a personal relationship with God in prayer; hope is associated with difficulties, sufferings, challenges, disappointments, problems; and love is related to the quality-of-life relationships with others and God [9].

The main issue on the aspect of spirituality facing by a person nowadays is the problems of the relationship with God in pray, faith, and love; less human relationship with others or neighbors; could not distinguish between good and bad, right and wrong; and feel no longer free to make joyful choices. Based on the above issues, several goals of spiritual direction can be drawn as follows: (1) helping individuals to grow and develop their personal relationship with God, (2) realizing God's presence in the entire individual's life, (3) living a relationship with God through relationships with others, trying to enjoy spiritual relationships with God, (4) being able to make a discernment between genuine and false experiences of God, (5) growing in spiritual, personal and social life, and (6) having great inner freedom to make life choices and to rejoice over the whole life as a gift and grace from God.

Spiritual direction does not mean only giving advice on good and bad, but also providing information as well as letting a person being guided to make right decisions. Spiritual direction is not therapy because therapy is usually carried out clinically, systematically, and in a structured manner by a professional (counselor, psychologist), while the spiritual direction is a spiritual guidance in which the role of spiritual counselor is only a facilitator who assist the one being guided by God. Moreover, spiritual direction focuses on growth-centered and not problemcentered. That means that it helps individuals to grow and develop their lives and is not focused on individual problems. Spiritual direction helps the guided to overcome life's problems in order to achieve a more mature life growth.

\subsection{Requirements for Spiritual Guides}

People often say that those who become spiritual guides are priests, pastors, monks, religious men, and women. But actually, the duty of spiritual guide is open to all, the most important thing is to fulfill the requirements. There are several qualifications of being a spiritual guide [10]. (a) Have a good spiritual life and with a quality of prayer life manifest in the practice 
of daily life. (b) Be able to reflect on every event and personal experience and interpret it in the light of God's experience. (c) Being able to share his prayer experiences, bitter and painful feelings with courage, and build empathy towards others. (d) Be able to build friendly relationships and open to being hurt for something that is right. (e) Have a great desire to grow and develop in faith and be able to overcome the desolation of spiritual life. (f) A psychologically and spiritually healthy person. (g) Be able to overcome personal difficulties and doubts of faith. (h) Realizing himself as a person who is used by God for something noble. ((i) Accepting his/herself with all his/her strengths and weaknesses and realizing his/herself as a unique person and loved by God. (j) Having a clear self-image as God's creation. And (k) being able to build relationships with God and others.

\subsection{The Role of Spiritual Direction}

As explained above that spiritual direction is not therapy, then what is the role of spiritual direction? It should be remembered that the media of spiritual direction are conversations or dialogues between spiritual guide and the guided in his personal relationship with God. There are several roles of spiritual direction, such as: (1) it provides an explanation, clarification of something that is unclear, hidden, or that threatens a guided person until he understands the obscurity. (2) It helps a guided person to make spiritual discernment to find out whether the Spirit of God or another spirit is speaking to him, what God is conveying, and how to do it. Discernment will determine what is good and right and what is wrong and false. (3) It facilitates a guided person to achieve the goal of spiritual direction, namely for the guided 's faith growth and maturation.

Mature faith appears in the attitude of knowing how to distinguish between good and bad, openness to God and others, diligently and faithfully worshiping and applying religious values in practical life, and so on. So as a whole it can be concluded that the role of spiritual direction is to help a guided person to understand, and interpret every life event and problem in terms of the experience of God, as well as to provide theological, spiritual, biblical, and moral religious information as a consideration in a process of growth and maturation of faith, hope, and love.

\subsection{Integration of Guidance and Counseling and Spiritual Guidance}

Guidance and counseling and spiritual direction are two helping relationship activities that can be carried out together. Both aims are to help the guided, counselee or client prevent, overcome, or develop themselves in a better direction. People who do counseling and spiritual direction is called spiritual counselors. At the same time, spiritual counselors can carry out counseling and guidance activities. The spiritual counselor first helps a counselee, a guided person to overcome his psychological problems, and after that comes to his personal relationship with God.

The assumption is that human is social, biological, personal, and spiritual [11]. Therefore, all aspects of human life must be carried out together to be discussed and try to look for the ways to overcome it. It means that the psychological dimensions in counseling and relationship with God in spirituality must be understood and integrated in assisting a counselee or guided person.

\subsection{Similarities and differences}

It has been implicitly explained above that spiritual direction and counseling psychology have similarities and differences. The similarities include: (1) Both talk about the experience of human life, use a democratic approach, and help individuals to grow and develop in freedom. (2) Having an attitude of mutual respect and trust, empathic listening, but also showing 
resistance, transferability, countertransference, and self-mechanisms. (3) Want a dynamic life and change for a better, peaceful, and calm direction [12].

In addition to the similarities, there are also differences, such as: (1) Focus and objectives: the purpose of counseling is problem-centered, it means that it focuses on the problem, so the purpose of counseling is to help the counselee to overcome his problems. Whereas the purpose of spiritual direction is growth-centered, it means that it focuses on the guided person growth and development, so the goal of spiritual direction is to help a guided person grow to a better direction in terms of faith, hope, and love. (2) Relationship: in counseling, there is a relationship between counselor and counselee, in which the counselor with his expertise, skills, and experience helps a counselee/client to overcome his psychological problems. Meanwhile, spiritual direction emphasizes on the relationship between a guided person and God. The presence of the spiritual director is only as a facilitator, who helps or facilitates the guided relationship with God. The guided must listen to the voice of God speaking. (3) Atmosphere: the counseling room must be comfortable and pleasant which makes the counselee feel at home and to be more open to counselor. Meanwhile, the spiritual direction room must be equipped with spiritual attributes such as Scripture, cross, burning candle, that show God's presence, the atmosphere is also calmer, meditative, and reflective. (4) Spiritual direction tries to distinguish whether wrong feelings are true or natural, whereas counseling looks at the complexity of neurotic feelings of wrong.

\subsection{Spiritual Counselor Skills}

As mentioned above, counselor in counseling and spiritual director in spiritual direction is called a spiritual counselor. In particular, he had sufficient knowledge of psychology, theology, and spirituality. Even though spiritual direction is not a therapy, but in principle it requires certain counseling skills. There are several basic skills that the spiritual counselor must possess [13].

First, physical attending, it relates to two things: (1) a comfortable and pleasant room, as well as supporting furniture and attributes such as sofas, tables, certain games, crosses, burning candles, the Scriptures (various spiritual attributes); (2) the open posture, expression, and tone of the spiritual counselor's voice are uplifting, strengthening, encouraging, but in certain situations, it can lead to confrontation.

Second, psychological attending, it means that the spiritual counselor was not physically present, but at the same time, he was present psychologically. The signs of spiritual counselor present psychologically, namely empathic listening to what a counselee / guided person says, being friendly and understanding what a counselee / guided person feels, paying attention and feeling interested in counselee / guided person experiences, etc.

Third, spiritual attending, which means that the spiritual counselor who has been present physically, biologically, and psychologically, shows the spiritual dimension, which is to hear attentively the counselee/the guided experiences with faith and in the power of the Holy Spirit. The spiritual counselor realizes that he is only a medium used by God to assist the guided / counselee. Another aspect of spiritual attending is a calm, contemplative atmosphere, which leads the person to become aware of God's liberating presence; the meeting begins and ends with a prayer; the room is equipped with crosses, burning candles, the Scriptures, and so on [14].

Fourth, attentive listening is one of the most important skills in counseling psychology and spiritual direction. Spiritual counselor listens attentively to what a counselee / guided person shares, and at the same time understands the message conveyed by a counselee through verbal and non-verbal language. 
Fifth, empathy, it is applied in counseling psychology and spiritual direction, empathy is the most important part of all helping skills. In particular, in spiritual direction, the spiritual counselor is expected to have the skills of understanding the counselee's/the guided' mind, to be able to enter into the guided person' situation and to think and feel like himself.

Sixth, the art of probing, it is related to the skill of asking questions for exploitation of the problems that a counselee / guided person share. The purpose of the art of probing is to clarify the content of problem, find out missing data, and broaden perspectives.

\subsection{Guidance and Counseling and Spiritual Direction Steps}

Guidance and counseling are carried out by a professional who has an educational background of at least undergraduate in the field of guidance and counseling psychology, has a mastery of guiding skills and theories, and is experienced in guidance. Meanwhile, spiritual direction is carried out by a priest, pastor, monk, religious men or women, and a layperson who has sufficient theological knowledge and psychology. Spiritual direction generally follows the counseling psychology structure and systematics, it's just that in certain stages it includes spiritual elements. Below is described the framework of spiritual direction and guidance and counseling according to the Carkhuff-Gazda Model [15].

\section{Guidance and Counseling}

\section{Summary of the "Carkhuff-Gazda" Model}

\section{Stages/Purpose}

Pre-Helping Stage:

- to create an atmosphere
conducive to sharing

\section{Stage I:}

- to facilitate self-exploration

Stage II:

- to deepen self-understanding

Stage III:

- to facilitate action
Helping skills Necessary

1. Physical attending of openness 2. Psychological attending

1. Empathy

2. Respect

3. Warmth/Caring

1. Concreteness/Specificity

2. Genuineness

3. Self-discloser

1. Confrontation

2. Immediacy

3. Support

\section{Counseling Spiritual Direction:}

Summary of Model Adding Spiritual Dimension
Stages/Purpose
Helping skills Necessary
Pre-Helping Stage:
1. Physical attending
- to create an atmosphere of openness 2. Psychological attending conducive to sharing
3. Spiritual attending
Stage I:
1. Empathy (Based on God-likeness)
- to facilitate self-exploration
2. Respect (Rooted in compassion) 
Stage II:

- to deepen self-understanding

Stage III

- to facilitate action
3. Warmth/Caring (Flowing from Love)

1. Concreteness/Specificity

2. Genuineness

3. Self-discloser

4. Prayer

1. Confrontation

2. Immediacy

3. Support (Involving the Christian Community)

The table above explains that there are three (3) stages/phases in spiritual direction process. Before entering the first stage, spiritual counselor first creates a comfortable and pleasant situation called building a rapport so that counselee / the guided can more easily share his personal experiences. Therefore, spiritual counselors must be aware of his/her physical, psychological, and spiritual attending.

The first stage, self-exploration. In this stage, the spiritual counselor facilitates the process of exploring the counselee / guided person's problems. The skills that must be played by spiritual counselors are the empathy attitude, both verbally and non-verbally by showing the quality of God's attitude who is always ready to hear and pay attention to every human being who admonishes Him. He/she also values counselee/guided person presence and accepts them for who they are with love and being friendly and love.

The second stage, deepening self-understanding. The purpose of guidance and counseling as well as spiritual guidance is to help a counselee / the guided to know who he is before God and fellow humans. Human is God's creation, a unique and special self, a self that has its strengths and weaknesses. In order to achieve this goal, spiritual counselor must speak clearly and specifically about getting to know himself, and in certain moments he can share his own experiences on how to get to know himself better. Another factor that can be used to understand the self is prayer. Without God's help, human efforts are in vain and may not produce anything. Therefore, in the whole process of spiritual direction, prayer is an alternative to solve life's problems.

The third stage, making concrete actions for a better life change. The purpose of spiritual direction is to assist the counselee/the guided to change bad attitude, and to be more positive and productive. In order to achieve this goal, spiritual counselors can engage in confrontation if a counselee / the guided is more dominated by irrational belief. Irrational thinking often sucks up a lot of useless energy and even hinders an individual from growing more mature in faith, hope, and love. Concrete actions to make self-change must also be supported by fellow believers.

\section{Conclusion}

Spiritual direction has similar structure and process to general guidance and counseling. Both of them have something in common, namely that they are both classified as helping relationship to assist counselee / guided person. While the difference lies in the role of counselor, atmosphere, and purpose. Spiritual direction is more Christian in nuance; therefore, the atmosphere is more reflective, meditative, and contemplative and the counselor presence is only as a facilitator who assist counselee / the guided to build his personal relationship with God. Therefore, it can be concluded that there is a connection between guidance and counseling 
psychology and Christian spiritual direction. Both approaches could be used in helping a person to deal with his problems.

\section{References}

[1] Telaumbanua, Kaminudin: Konsep Dasar Bimbingan dan Konseling, Jurnal Warta Edisi, Vol. No. 49. No 2. 2016).

[2] Harisa, Arizka: The Influence of Counseling Guidance and Spiritual Intelligence in Developing Students' Islamic Personality. Jurnal Pendidikan Islam, Vol. 5, No. 1, pp. 75-86 (2019).

[3] Sari, Milya \& Asmendri: Penelitian Kepustakaan (Library Reseach) dalam Pendidikan Ipa, Natural Science, Jurnal Bidang Ipa dan Pendidikan Ipa (Online), Vol 6 (1), 41-53 (2020).

[4] Willis, Sofyan: Konseling Individual Teori dan Praktek. pp. 10-16. Alfabeta, Bandung, (2004).

[5] Glading, Samuel: Counseling A Comprehensive Profession. pp. 4-7. Precentile Hall, Ohio, USA. (2000).

[6] Willis, Sofyan, Op. Cit. pp. 18-20.

[7] Prayitno, H: Dasar-Dasar Bimbingan dan Konseling. pp. 194-217. Rineka Cipta, Jakarta, (199).

[8] Laka Lazar, Fransiskus: Integrasi Psikologi Konseling dalam Spiritual Direction: Sebuah Pendekatan Psiko-Spiritual, pp. 129. Jurnal Pendidikan dan Kebudayaan Missio, Vol. 11, No. 1, pp. 126-135 (2019).

[9] Ibid. pp. 130.

[10] Saprudin, Ujung: Konsep Bimbingan dan Konseling Spiritual: Kerangka Kerja Untuk Guru Bimbingan dan Konseling. Jurnal Penelitian Bimbingan dan Konseling, Vol. 4, No. 1. (2019).

[11] Darminta, J: Praksis Bimbingan Rohani, pp. 51-52. Kanisius, Yogyakarta, (2006).

[12] Ibid. pp. 75-79.

[13] Ferris, Margaret: Compassioning, Basic Counseling Skills for Christian Care-Giver, pp. 15-20. Kansas City: Sheed \& Ward, (1993).

[14] Ibid. pp. 5-10.

[15] Ibid. pp.1-4. 